\title{
PENERAPAN MODEL PEMBELAJARAN LANGSUNG DALAM MENINGKATKAN PRESTASI BELAJAR SISWA PADA MATA PELAJARAN FIQIH
}

\author{
Muh. Zulkifli, Rosli Hady \\ Dosen Tetap IAI Hamzanwadi NW Lombok Timur \\ Email: muhzulkfli2310@gmail.com
}

\begin{abstract}
Abstrak: Menghadapi era globalisasi yang penuh dengan persaingan dan ketidak puasan dibutuhkan guru yang visioner yang mampu mengelola proses belajar mengajar secara efektif dan inovatif di dalam kelas. Juga diperlukan perubahan strategi dan model pembelajaran yang sedemikian rupa sehingga dapat memberikan nuansa yang menyenangkan bagi guru dan peserta didik, sehingga tujuan pendidikan itu dapat tercapai atau berdaya guna. Salah satu cara untuk meningkatkan hasil belajar adalah dengan menerapkan model pembelajaran langsung. Pada penelitian ini bertujuan untuk mengetahui bagaimana penerapan model pembelajaran langsung pada mata pelajaran fiqih dalam meningkatkan prestasi siswa di kelas VII MTs Babussalam NW Pengadang Baru, kendala apa saja yang menghambat meningkatnya prestasi belajar siswa. Penelitian ini menggunakan pendekatan deskriptif kualitatif. Dalam pengumpulan data metode yang digunakan adalah metode wawancara, tes, dokumentasi, dan observasi. Berdasarkan hasil penelitian yang diperoleh dapat disimpulkan bahwa penerapan model pembelajaran langsung dalam meningkatkan prestasi belajar siswa pada mata pelajaran fiqih sudah berhasil dan efektif. Hal ini dapat di lihat dari meningkatnya pemahaman siswa dan keterampilan siswa dalam melaksanakan tata cara taharah. Sehingga prestasi yang dicapai meningkat dan maksimal.
\end{abstract}

\section{Kata kunci: Model Pembelajaran Langsung, Prestasi Belajar}

Abstract: Facing an era of globalization full of competition and dissatisfaction, there is a need for visionary teachers who are able to manage the teaching and learning process effectively and innovatively in the classroom. It is also necessary to change learning strategies and models in such a way that it can provide a pleasant atmosphere for teachers and students. so that educational goals can be achieved or efficient. One way to improve learning outcomes is to apply a direct learning model. This study aims to find out how the application of direct learning model to fiqh subjects in improving student achievement in class VII MTs Babussalam NW Pengadang Baru, what are the barriers that hinder student achievement. This research uses a qualitative descriptive approach. In collecting data the methods used were interviews, tests, documentation, and observations. Based on the results of the study, it can be concluded that the application of the direct learning model in improving student achievement in the subject of figh has been successful and effective. This can be seen from the improvement of students' understanding and skills in performing taharah procedures. So that the achievements achieved are increased and maximized

Keywords: Direct Learning Model, Learning Achievement 


\section{PENDAHULUAN}

Dalam Undang-Undang No. 20 Tahun 2003 pasal 1ayat 1 Tahun 2003 tentang Sistem Pendidikan Nasional, dinyatakan "pendidikan adalah usaha sadar dan terencana untuk mewujudkan suasana belajar dan proses belajar agar peserta didik secara aktif membangun potensi dirinya untuk memiliki kekuatan spiritual keagamaan, pengendalian diri, kepribadian, kecerdasan, akhlak mulia, serta keterampilan yang diperlukan dirinya, masyarakat, bangsa dan negara."

Berdasarkan pengertian di atas, pendidikan dilakukan secara sengaja untuk memotivasi dalam membangun dan mengembangkan potensi yang dimiliki oleh seseorang sehingga menjadi pribadi yang lebih baik. Pendidikan tidak terlepas dari kehidupan manusia, dengan pendidikan manusia dapat berguna bagi Negara dan bangsa. Selain itu pendidikan juga sangat penting dalam usaha pendewasaan manusia, baik oleh dirinya sendiri maupun dilakukan oleh orang lain.

Pendidikan merupakan faktor utama yang menentukan kualitas dan mutu suatu bangsa. Pendidikan bukanlah suatu yang bersifat statis melainkan bersifat dinamis sehingga pendidikan selalu menuntut suatu perubahan yang bersifat terus menerus. Pendidikan berperan penting dalam meningkatkan kecerdasan dan keterampilan, oleh karena itu pembaharuan pendidikan terus selalu dilakukan untuk meningkatkan kualitas pendidikan Nasional.

Pendidikan bertujuan untuk membangun moral dan akhlak manusia sehingga dalam pendidikan juga disebut pendidikan Agama terutama pendidikan Agama Islam. Zuhairi mengartikan bahwa Pendidikan Agama Islam (PAI) sebagai usaha sadar secara sistematis dan pragmatis dalam membantu peserta didik supaya mereka hidup sesuai dengan ajaran Islam. Sedangkan menurut Zakiyah Daradjat, Pendidikan Agama Islam adalah suatu usaha untuk membina dan mengasuh peserta didik agar senantiasa dapat memahami ajaran Islam secara menyeluruh lalu menghayati tujuan yang pada akhirnya dapat mengamalkan serta menjadikan Islam sebagai pandangan hidup (Wiyani, 2016: 46).

Jadi, Pendidikan Agama Islam adalah usaha sadar untuk menyiapkan siswa dalam meyakini, memahami, menghayati dan mengamalkan Agama Islam melalui kegiatan bimbingan, pengarahan atau latihan dengan memperhatikan tuntutan untuk menghormati agama lain dalam hubungan kerukunan antar umat beragama dalam masyarakat untuk mewujudkan kesatuan Nasional. Pendidikan sendiri tidak terlepas dari kegiatan pembelajaran. Belajar menurut Spears dalam Suprijono (2009: 2) adalah mengamati, membaca, meniru, mencoba sesuatu, mendengar, dan megikuti arah tertentu. Jadi, belajar merupakan kegiatan penting bagi setiap orang, termasuk didalamnya belajar bagaimana seharusnya belajar (Aunurrahman, 2016: 33).

Belajar mungkin saja terjadi tanpa pembelajaran, namun pengaruh aktivitas pembelajaran dalam belajar hasilnya lebih sering menguntungkan dan biasanya lebih mudah diamati. Pembelajaran sendiri berupaya mengubah masukan berupa siswa yang belum terdidik, menjadi siswa yang terdidik, siswa yang belum memiliki pengetahuan tentang sesuatu, menjadi siswa yang memiliki pengetahuan. Demikian pula siswa yang memiliki sikap, kebiasaan atau tingkah laku yang belum mencerminkan eksistensi dirinya sebagai pribadi baik atau positif, menjadi siswa yang memiliki sikap, kebiasaan dan tingkah laku yang baik (Aunurrahman,2016: 34).

Keberhasilan proses pembelajaran tidak terlepas dari kemampuan guru dalam mengembangkan model-model pembelajaran yang berorientasi pada peningkatan intensitas keterlibatan siswa secara efektif di dalam proses pembelajaran. Pengembangan model pembelajaran yang tepat pada dasarnya bertujuan untuk menciptakan kondisi pembelajaran 
yang memungkinkan siswa dapat belajar secara aktif dan menyenangkan sehingga siswa dapat meraih hasil belajar dan prestasi yang optimal (Aunurrahman, 2016: 140).

Guru adalah seorang yang bertanggung jawab atas pendidikan perkembangan anak didik baik itu di sekolah maupun diluar sekolah. Seorang guru harus mampu dalam berbagai bidang karena guru adalah seorang pendidik yang akan melaksanakan tindakan mendidik guna mencapai tujuan dari pendidikan tersebut. Untuk mencapai tujuan dari pendidikan tersebut guru harus memiliki cara pendekatan belajar mengajar yang dianggap paling tepat untuk mencapai sasaran, atau dengan kata lain guru harus memiliki metode atau model pembelajaran tertentu supaya efektif dalam kegiatan belajar mengajar sehingga tercapailah tujuan pembelajaran yang diharapkan.

Menurut E. Mulyasa (2002: 101) dalam kegiatan pembelajaran, tugas guru adalah memberikan kemudahan belajar melalui bimbingan dan motivasi untuk mencapai tujuan. Guru sebagai unsur pokok penanggung jawab terhadap pelaksanaan dan pengembangan proses belajar mengajar, diharapkan dapat meningkatkan kualitas proses belajar mengajar yang merupakan inti dari kegiatan transfer ilmu pengetahuan dari guru ke siswa. Proses belajar mengajar ini bisa terjadi dimana saja, kapan saja, oleh siapa saja, untuk mendesain kegiatan belajar yang dapat merangsang proses dan hasil belajar yang efektif dan efisien dalam setiap materi pelajaran maka diperlukan strategi atau metode penyampaian materi yang tepat. Dalam praktek pendidikan di kelas selain ditandai dengan peran guru yang lebih dominan juga ditandai dengan siswa yang hanya menghafalkan materi pelajaran saja. Hal ini sering terjadi dalam proses pembelajaran terutama dalam pelajaran fiqih. Para siswa menganggap bahwa dengan menghafal materi pelajaran sudah dapat menguasai materi pelajaran untuk mendapatkan hasil belajar yang maksimal. Sedangkan mata pelajaran fiqih merupakan suatu pelajaran yang dirancang untuk membentuk pribadi, sikap, serta keterampilan siswa dalam menjalankan atau mempraktikkan ibadah dan mengamalkan hukum-hukum Islam untuk diterapkan dalam kehidupan sehari-hari. Dalam dunia pendidikan sudah banyak perubahan, sehingga perlu adanya pembaharuan model pembelajaran terutama pada mata pelajaran fiqih. Salah satu model pembelajaran yang tepat dalam proses belajar mengajar pada mata pelajaran fiqih adalah model pembelajaran langsung. Karena dalam pelajaran fiqih tidak hanya menyampaikan materi saja kepada peserta didik melainkan harus di barengai dengan praktik langsung di depan peserta didik, sehingga peserta didik dapat merasakan hasil dari pembelajaran tersebut baik berupa materi pelajaran maupun dalam pengamalannya.

MTs Babussalam NW Pengadang Baru merupakan sebuah Madrasah di Desa Mumbul Sari Kecamatan Bayan yang memiliki siswa sebanyak 66 orang. Siswa di sekolah ini berasal dari beberapa wilayah di Desa Mumbul Sari dengan memilki latar belakang dan pengetahuan yang berbeda-beda. Tidak terkecuali di kelas VII. Siswa kelas VII di MTs Babussalam kurang dilibatkan secara aktif dalam proses pembelajaran, siswa hanya mendengarkan penjelasan dari guru dan mencatat materi pelajaran saja, hal ini dapat menyebabkan siswa kurang dalam mengembangkan keterampilan, berfikir dan bersikap dalam menjalankan ibadah sehari-hari. Siswa kelas VII masih bersikap pasif dan kurang memperhatikan guru dan berpartisipasi sehingga kurangnya pengetahuan serta keterampilan, kondisi seperti ini jelas berdampak kurang baik bagi siswa, sehingga dalam penerapan model pembelajaran langsung masalah-masalah yang timbul dari siswa tersebut dapat diatasi secara khusus pada mata pelajaran fiqih di kelas VII MTs Babussalam NW Pengadang Baru 


\section{METODE PENELTIAN}

Metode penelitian yang digunakan dalam penelitian ini adalah penelitian kualitatif yaitu penelitian yang bersifat deskriptif dan cendrung menggunakan analisis. Proses dan makna lebih ditonjolkan dalam penelitian kualitatif. Landasan teori yang dimanfaatkan sebagai pemandu agar focus penelitian sesuai dengan fakta dilapangan. Metode penelitian kualitatif adalah metode penelitian yang bermaksud untuk memahami fenomena tentang apa yang dialami oleh subjek penelitian misalnya prilaku persepsi, motivasi, tindakan dan lainlain secara holistic, dan dengan cara dekripsi dalam benuk kata-kata dan bahasa pada suatu konteks khusus yang alamiah dan dengan memanfaatkan berbagai metode alamiah. Adapun Penelitian ini bertujuan untut dapat mengetahui bagaimana penerapan model pembelajaran langsung dalam meningkatkan prestasi belajar siswa pada mata pelajaran Fiqih kelas VII di kelas VII MTs Babussalam NW Pengadang Baru, dan juga untuk dapat mengetahui kendalakendala dalam menerapkan model pembelajaran langsung.

\section{PEMBAHASAN}

\section{Penerapan Model Pembelajaran Langsung Pada Mata Pelajaran Fiqih di Kelas VII MTs Babussalam NW Pengadung Baru}

Salah satu cara untuk dapat meningkatkan prestasi siswa menjadi lebih baik adalah dengan penerapan model pembelajaran langsung, sehingga apa yang diharapkan dapat tercapainya tujuan belajar. Dan dalam proses pembelajaran seorang guru juga membutuhkan sumber belajar. Dengan adanya sumber belajar, maka suatu kegiatan belajar mengajar akan lebih efektif dan efisien dalam usaha pencapaian tujuan yang telah ditetapkan. Sumber belajar adalah segala sesuatu yang diperlukan dalam proses pembelajaran, yang dapat berupa buku teks, media cetak, media pembelajaran elektronik, nara sumber, lingkungan alam sekitar, dan sebagainya. Suber belajar dipilih berdasarkan pada kompetensi, materi pembelajaran, kegiatan pembelajaran, dan indikator pencapaian kompetensi dasar. Keaktifan belajar tidak dapat dilepaskan dari kaitannya dengan sumber belajar yang digunakan. "Penggunaan sumber belajar sangat penting digunakan oleh seorang guru untuk mendukung peningkatan prestasi siswa, misalnya: dengan penggunaan alat, pendekatan dan metode, strategi pengajaran dan sebagainya. (wawancara kepala sekolah : Siti Rauhun, S.Ag, selasa 11 Agustus 2020, pukul 09: 32).

Dari hasil wawancara di atas jelas bahwa penggunaan sumber belajar sangatlah penting dalam proses belajar mengajar. Hal ini dapat mengatasi kesulitan belajar siswa dan penggunaan sumber belajar tersebut benar-benar dapat difungsikan untuk meningkatkan prestasi belajar siswa. Penggunaan alat dalam metode demonstrasi juga mendukung dalam menerapkan model pembelajaran langsung. Hal ini sesuai dengan sintak model pembelajaran langsung tersebut. Dengan menggunakan model pembelajaran langsung dengan metode demonstrasi pada pelajaran fiqih ini, maka keterampilan dan penguasaan pengetahuan siswa dapat meningkat, terutama siswa dapat menerapkan keterampilan yang diperolehnya dalam menjalankan ibadah seharihari (wawancara guru, M. Alimudin, QH., S.Pd, 03 september 2020, pukul 10: 15).

Pada penerapan model pembelajaran langsung ini, peneliti menggunakan metode demonstrasi agar siswa dapat dengan mudah dalam memahami dan menerima pelajaran. Dengan menggunakan metode demonstrasi siswa tidak lagi merasa jenuh dan bosan saat mengikuti proses belajar, sebaliknya siswa terlihat antusias dan bersemangat dalam memperhatikan penjelasan guru saat mendemonstrasikan perilaku yang berkaitan dengan materi pelajaran. Setiap model pembelajaran yang akan diterapkan dalam suatu kegiatan belajar mengajar tentu akan memiliki langkah-langkah atau strategi yang akan di 
tempuh oleh guru agar siswa dapat menerima dan memahami pelajaran tersebut dengan lebih mudah dan maksimal. Oleh karena itu seorang guru harus menguasai strategi yang digunakan dalam proses belajar mengajar. Adapun langkah-langkah yang di tempuh oleh seorang guru dalam penerapan model pembelajaran langsung pada mata pelajaran fiqih dalam meningkatkan prestasi siswa di kelas VII MTs Babussalam NW Pengadang Baru Desa Mumbul Sari Kecamatan Bayan Kabupaten Lombok Utara adalah

a. Tahap Perencanaan

1) Menyiapkan RPP

Berdasarkan pernyataan tersebut bahwa menyiapkan sebuah RPP sebelum melakukan pembelajaran sangat penting, karena dengan berpedoman kepada RPP ini, pengajar akan dapat mengajar dengan sistematis tanpa harus khawatir keluar dari ruang lingkup materi ataupun strategi pembelajaran. RPP mempunyai beberapa manfaat dalam proses pembelajaran diantaranya, dapat mempermudah, memperlancar dan meningkatkan hasil proses belajar mengajar, sebagai acuan guru untuk melaksanakan kegiatan pembelajaran agar lebih terarah dan berjalan secara efektif dan efisien, dan RPP memberikan landasan pokok bagi guru dan siswa dalam mencapai kompetensi dasar dan indikator.

2) Menyiapkan Lembar Observasi Aktivitas Siswa dan Guru

Kegiatan observasi bertujuan untuk memperoleh informasi tentang tingkah laku, keadaan, kondisi, atau situasi dari objek yang di teliti. Untuk dapat merealisasikan kegiatan observasi maka dibuatlah lembar observasi. Secara khusus lembar observasi dimaksudkan guna mengukur tingkat keberhasilan penelitian dalam penerapan model pembelajaran langsung pada mata pelajaran fiqih dalam meningkatkan prestasi siswa di kelas VII MTs Babussalam NW Pengadang Baru.

3) Menyiapkan Lembar Penilaian Siswa

Penilaian dilakukan setelah siswa menjawab beberapa soal yang terdapat pada tes. Kemudian hasil jawaban siswa tersebut di tafsirkan dalam bentuk nilai. Untuk itu di buatlah lembar penilaian yang bertujuan untuk merangkum semua datadata nilai siswa yang diperoleh kemudian dengan nilai-nilai siswa tersebut dapat diperoleh nilai rata-rata yang akan memperlihatkan presentasi keberhasilan dari penerapan model pembelajaran langsung pada mata pelajaran fiqih dalam meningkatkan prestasi siswa di kelas VII MTs Babussalam Nw Pengadang Baru.

b. Tahap Pelaksanaan

1) Kegiatan Awal

a) Berdo'a

Sebelum melakukan kegiatan pembelajaran terlebih dahulu para siswa mengucapkan salam begitu guru masuk kelas. Kemudian guru (peneliti) mengatur posisi duduk para siswa kemudian mempersilahkan ketua kelas untuk memimpin doa, ketua kelas pun menyiapkan teman-temannya untuk berdoa baik di awal maupun di akhir pembelajaran. Siswa terlihat mengikuti instruksi dari ketua kelas untuk berdo'a. Selain itu guru juga ikut berdo'a dengan menunjukkan berdoa yang khusuk tanpa mengerjakan aktivitas yang lain, sikap seperti itu diharapkan menjadi tauladan bagi siswa.

Hasil wawancara juga mendukung hal tersebut, dalam wawancara tersebut ibu rauhun mengungkapkan "berdoa dilakukan setelah mengkondisikan kelas, suruh ketua kelas untuk menyiapkan teman-temannya dan memimpin doa. Jika ada siswa yang mengobrol atau main-main pada saat berdoa, pertama guru 
memandang siswa tersebut kalau tidak berubah maka setelah berdoa selesai siswa tersebut di suruh berdoa sendiri" (wawancara kepala sekolah: Siti Rauhun, S.Ag, Selasa 11 Agustus 2020, pukul 09: 32).

Dari hasil pengamatan selama berdo'a, sebagian besar siswa membaca doa dengan khusuk, sebagian lagi masih ada siswa yang saling melirik dan mengobrol namun hanya sebentar. Pada saat berdo'a siswa membaca solawat nahdlatain, doa untuk orang tua, doa supaya selamat dunia akhirat dan doa belajar.

b) Kegiatan Mengabsensi Kehadiran Siswa

Setelah kegiatan berdo'a, guru melakukan kegiatan absensi terhadap kehadiran siswa satu persatu untuk mengetahui siswa yang hadir maupun tidak hadir, selain itu guru juga bisa mengenali satu persatu siswanya yang masuk sekolah dan tidak masuk sekolah. "kegiatan absensi juga perlu dilakukan sebelum melakukan pembelajaran, karena dengan melakukan kegiatan absensi diharapkan supaya siswa lebih meningkatkan kedisiplinan siswa. Selain itu guru juga bisa melihat kehadiran siswa" (wawancara guru, M. Alimudin, QH., S.Pd, kamis 03 September 2020, pukul 10: 15).

c) Menyampaikan Tujuan Pembelajaran atau Kompetensi yang akan di Capai

Pada kegiatan pendahuluan ini guru menyapaikan tujuan dari pembelajaran fiqih khususnya pada materi hadast kecil dan tata cara taharahnya di kelas VII di antaranya adalah supaya siswa:

Siswa dapat menyebutkan pengertian hadast kecil

(1) Siswa dapat menyebutkan tata cara membersihkan hadast keci

(2) Siswa dapat menyebutkan syarat dan rukun wudhu

(3) Siswa dapat menyebutkan sunnah-sunnah wudhu

(4) Siswa dapat menyebutkan hal-hal yang membatalkan wudhu

(5) Siswa dapat mempraktikkan wudhu

"Sebelum melakukan pembelajaran sebaiknya seorang guru memang harus menyampaikan tujuan dari pebelajaran tersebut supaya siswa lebih termotivasi dalam belajar dan mencapai hasil yang diinginkan, terutama siswa dapat menerapkannya dalam kehidupan sehari-hari" (wawancara guru, Subhanudin, S.Pd.I, kamis 13 Agustus 2020, pukul: 10: 22).

2) Inti

Sebelum guru menjelaskan dan menyampaikan materi pelajaran, guru terlebih dahulu memberikan tes berupa pertanyaan kepada siswa yang berkaitan dengan materi pelajaran untuk mengukur pemahaman siswa sebelum siswa menggunakan model pembelajaran langsung dengan metode demonstrasi. Setelah itu sesuai dengan fase ke dua dari sintak model pembelajaran langsung yaitu fase Demonstrating (Mendemonstrasikan pengetahuan atau keterampilan) yaitu dimana guru Mendemonstrasikan keterampilan yang benar, menyajikan informasi tahap demi tahap. Disini terlebih dahulu guru mendemonstrasikan materi yang sedang di pelajari yaitu materi tentang hadas kecil dan tata cara taharah dalam hal ini guru mempraktikkan cara berwudhu. Selama guru mempraktikkan cara berwudhu, siswa memperhatikan dengan baik walaupun masih ada siswa yang tidak memperhatikan penjelasan dari guru dan membuat keributan kecil.

Setelah selesai melakukan demonstrasi dan menyampaikan penjelasan kepada siswa, guru lalu melanjutkan pada fase ke tiga yaitu fase Guide Practice (Membimbing pelatihan) yaitu dimana guru Merencanakan dan memberi pelatihan 
awal. Di sisni guru meminta para siswa untuk mempraktikkan apa yang sudah dipraktikkan oleh guru di depan kelas dengan melakukan bimbingan kepada siswa.

3) Penutup

Pada tahap ini sebelum guru menutup pembelajaran terlebih dahulu guru mengecek pemahaman dan memberikan umpan balik kepada siswa yaitu guru Mengecek apakah peserta didik telah berhasil menguasai materi dengan baik dengan memberikan pertanyaa kepada siswa. Dengan begitu dapat diketahui sampai mana pemahaman siswa terhadap materi yang telah dipelajari. Kemudian guru memberikan kesempatan untuk pelatihan lanjutan dan penerapan yaitu guru Mempersiapkan kesempatan melakukan pelatihan lanjutan secara mandiri, dengan perhatian khusus pada penerapan kepada situasi lebih kompleks dalam kehidupan sehari-hari.

c. Tahap Observasi

Pada tahap observasi, peneliti melakukan pengamatan secara langsung selama proses belajar mengajar berlangsung. Guru mengamati setiap gerak gerik atau tingkah laku yang dilakukan oleh siswa hingga kegaduhan yang ditimbulkan oleh siswa dan guru mengamati siswa yang aktif dalam berinteraksi dengan guru. Berdasarkan hasil pengamatan dan wawancara kondisi kelas sebelum menggunakan model pembelajaran langsung terlihat tidak aktif dan cenderung peserta didik terlihat jenuh dan ingin keluar kelas secepatnya. Berbeda saat setelah menggunakan model pembelajaran langsung, peserta didik terlihat antusias dan bersemangat dalam mengikuti pelajaran dikarenakan siswa dilibatkan secara aktif dalam proses pembelajaran. Dengan penerapan model pembelajaran langsung ini menunjukkan bahwa keaktifan tidak hanya dari guru akan tetapi juga dari siswa, sehingga ada keseimbangan antara guru dengan siswa.

Penerapan model pembelajaran langsung dengan metode demonstrasi memiliki dampak yang positif dalam proses belajar mengajar di kelas, diantaranya adalah siswa menjadi termotivasi, keaktivan siswa dalam proses pembelajaran meningkat, keaktifan guru dalam membimbing, mengarahkan dan mengevaluasi, serta hasil dan tujuan dari pebelajaran tersebut dapat tercapai secara optimal. Hal ini dapat dilihat dari kegiatan belajar mengajar yang berlangsung:

1) Keadaan Siswa

Keaktifan siswa dapat dilihat dari kegiatan awal, inti sampai pada kegiatan penutup yaitu pada saat kegiatan awal siswa sudah terlihat aktif, hal ini dapat di dilihat dari kekompakan dalam berdo'a dan memperhatikan guru yang sedang menyapaikan tujuan dari pembelajaran yang akan dilaksanakan. Kemudian pada saat kegiatan inti berlangsung suasana kelas menjadi lebih hidup karena keantusiasan siswa dan keaktifan siswa dalam dalam mengikuti kegiatan belajar mengajar, misalnya pada saat mempraktikkan cara berwudhu, adanya interaksi antara guru dan siswa. Adapun pada tahap akhir siswa aktif bertanya tentang apa yang yang tidak dimengerti oleh mereka dan menjawab pertanyaan-pertanyaan yang dilontarkan oleh guru.

2) Keadaan Guru

Keaktifan guru dapat di lihat pada saat proses belajar mengajar berlangsung. Mulai dari kegiatan awal, inti, sampai dengan kegiatan akhir. Kegiatan-kegiatan tersebut dapat dijelaskan sebagai berikut:

a) Sebelum metode pembelajaran di mulai guru terlebih dahulu menjelaskan tujuan pembelajaran atau kompetensi yang akan dicapai siswa setelah 
mempelajarai materi pelajaran.

b) Mendemonstrasikan tata cara berwudhu di depan kelas. Dengan mendemontrasikan tata cara wudhu di depan kelas guru berharap siswa dapat merekam dengan baik setiap gerakan dan penjelasan yang diberikan oleh guru.

c) Membimbing siswa pada saat praktik. Pada saat siswa melakukan praktik tata cara berwudhu, guru tidak hanya melihat siswa praktik tetapi guru juga membimbing siswa supaya siswa dapat memperbaiki setiap kesalahankesalahan yang terjadi saat praktik.

d) Guru memberikan umpan balik kepada siswa. Umpan balik diberikan oleh guru supaya siswa dapat mengingat kembali materi yang dipelajari dan guru dapat mengetahui tingkat penguasaan siswa.

e) Mengawasi dan mengontrol belajar siswa di kelas. Guru berberan aktif dalam mengawasi proses belajar siswa. Dari membimbing siswa yang merasa kesulitan dalam belajarnya, menangani siswa yang nakal dan mengganggu temannya yang sedang belajar.

"Aktivitas belajar siswa di kelas khususnya pada mata pelajaran fiqih setelah menggunakan model pembelajaran langsung dengan metode demonstrasi terlihat sangat antusias dan bersemangat, hal ini dapat terlihat dari seluruh siswa yang terlibat aktif dalam proses pembelajaran terlebih ketika praktik. Sehingga dengan semangat dan keaktifan siswa dalam mengikuti pembelajaran tersebut dapat meningkatkan hasil belajar" (wawancara guru, M. Alimudin, QH., S.Pd., Kamis 03 September 2020 pukul 10:15).

Jadi, dari hasil wawancara di atas ternyata model pembelajaran langsung dengan menggunakan metode demonstrasi pada mata pelajaran fiqih sangat efektif dan efisien untuk dipergunakan dalam proses belajar mengajar karena dapat meningkatkan pengetahuan dan keterampilan siswa sehingga tercapailah prestasi siswa seperti yang diharapkan.

\section{Kendala-Kendala dalam Penerapan Model Pembelajaran Langsung (Direct Learning) Pada Mata Pelajaran Fiqih Kelas VII di MTs Babussalam NW Pengadang Baru}

Proses kegiatan belajar mengajar, memang tidak selalu berjalan dengan lancar tetapi terkadang ada kendala-kendala yang menyebabkan tujuan-tujuan yang sudah ditetapkan tidak terlaksana dengan baik. Dengan adanya problematika tersebut menuntut pihak pendidik untuk lebih memperhatikan peserta didik dan meningkatkan peran agar masalah tersebut dapat disikapi. Adapun kendala-kendala yang dihadapi pendidik dalam penerapan model pembelajaran langsung pada mata pelajaran fiqih dalam meningkatkan prestasi siswa di kelas VII MTs Babussalam NW Pengadang Baru Desa Mumbul Sari Kecamatan Bayan Kabupaten Lombok Utara sebagai berikut:

a. Kurangnya sarana yang disediakan oleh sekolah

b. Ketidak disiplinan peserta didik dalam memasuki ruang kelas ketika waktunya masuk kelas

c. Rentang waktu yang jauh dalam pelaksanaan jadwal pelajaran di karenakan pandemic covid-19

d. Media pembelajaran yang tidak memadai

e. Keanekaragaman masalah yang ada pada diri peserta didik yang memerlukan 
penangan di sela-sela pembelajaran yang sedang berlangsung

Demikian kendala-kendala yang penulis temukan di MTs Babussalam NW Pengadang Baru melalui informasi-informasi yang diberikan. Berdasarkan kendalakendala yang dipaparkan di atas tentunya sebagai pendidik dapat menemukan solusi dalam mengatasi problematika tersebut demi tercapainya hasil belajar siswa yang diinginkan.

\section{Prestasi Belajar Siswa Menggunakan Model Pembelajaran Langsung (Direct Learning) Pada Mata Pelajaran Fiqih Kelas VII di MTs Babussalam NW Pengadang Baru}

Siswa tidaklah cukup hanya mencapai prestasi saja selama belajar di sekolah, melainkan haruslah bersunggung-sungguh, bertekad dan berikhtiar agar menjadi siswa yang berprestasi dan mampu mengaplikasikan keterampilannya dalam kehidupan seharihari. Seorang siswa yang berprestasi adalah siswa yang penuh semangat untuk maju dan penuh gairah untuk melakukan belajar dalam mencapai keterampilan yang baik yang ditunjukkan untuk membentuk dan mengembangkan berbagai kebiasaan yang baik pada diri siswa.

Dalam proses pembelajaran pendidik memiliki peran yang sangat penting dalam menentukan kualitas pembelajaran, karena pembelajaran merupakan alat untuk mencapai tujuan pendidikan. Oleh sebab itu guru sebagai fasilitator di tuntut untuk memahami dan menguasi berbagai macam strategi pembelajaran yang membuat siswa aktif dan kreatif dalam proses pembelajaran. Hal ini dimaksudkan supaya peserta didik dapat belajar dengan menggunakan berbagai model, strategi atau cara agar peserta didik dapat melalui proses pebelajaran dengan hasil yang maksimal. Model pembelajaran langsung merupakan suatu model pembelajaran yang menekankan pada penguasaan konsep dan/atau perubahan perilaku dengan mengutamakan pendekatan deduktif, dengan cirri-ciri sebagai berikut:

a. Transformasi dan keterampilan secara langsung

b. Pembelajaran berorientasi pada tujuan tertentu

c. Materi pembelajaran yang telah terstruktur

d. Lingkungan belajar yang telah terstruktur dan

e. Di struktur oleh guru

Pada penjelasan diatas guru berperan sebagai penyampai informasi, dalam hal ini guru seyogyanya menggunakan berbagai media yang sesuai, misalnya film, tape recorder, gambar, peragaan, dan sebagainya. Informasi yang di sampaikan dapat berupa pengetahuan prosedural (yaitu pengetahuan tentang bagaimana melaksanakan sesuatu) atau pengetahuan deklaratif (yaitu pengetahuan tentang sesuatu dapat berupa fakta, konsep, prinsip, atau generalisasi).

Sebelum menggunakan model pembelajaran langsung prestasi siswa kelas VII di MTs Babussalam NW Pengadang Baru masih terlihat rendah. Hal ini dikarenakan metode yang diggunakan dalam proses belajar mengajar masih menggunakan metode konvensional (Ceramah). Dengan menggunakan metode ini siswa cenderung terlihat bosan dan minat belajar kurang sehingga dapat mempengaruhi hasil belajar siswa. Prestasi belajar siswa sebelum menggunakan model pembelajaran langsung dapat di lihat pada tabel di bawah ini: 
Tabel 1

Nilai Siswa Sebelum Menggunakan Model Pembelajaran Langsung

\begin{tabular}{clrcc}
\hline No Nama & & KKM & Poste & Ket \\
\hline 1 & Abdul Aziz Maqbul & 75 & 60 & Tidak Tuntas \\
2 & Ana Attopun Nisa & 75 & 75 & Tuntas \\
3 & Azizah & 75 & 80 & Tuntas \\
4 & Dani Isbullah & 75 & 65 & Tidak Tuntas \\
5 & Denil Arista Pratama & 75 & 65 & Tidak Tuntas \\
6 & Desi Lestari & 75 & 75 & Tuntas \\
7 & Desi Safitri & 75 & 80 & Tuntas \\
8 & Endri Setiawan & 75 & 65 & Tidak Tuntas \\
9 & Elsa Sulistia & 75 & 80 & Tuntas \\
10 & Eli Apriana & 75 & 65 & Tidak Tuntas \\
11 & Habib Burhanudin & 75 & 55 & Tidak Tuntas \\
12 & Jani Aprilia & 75 & 75 & Tuntas \\
13 & L Ahmad Aldinata & 75 & 60 & Tidak Tuntas \\
14 & M. Alparizi & 75 & 55 & Tidak Tuntas \\
15 & Moh. Kamaludin & 75 & 65 & Tidak Tuntas \\
16 & M. Kian & 75 & 55 & Tidak Tuntas \\
17 & Moh. Riski Pratama & 75 & 65 & Tidak Tuntas \\
& M. Yogi Akbar & 75 & 70 & Tidak Tuntas \\
19 & Raka Deny S & 75 & 65 & Tidak Tuntas \\
20 & Winda Rohana & 75 & 85 & Tuntas \\
21 & Serlina & 85 & Tuntas \\
\hline & Jumlah & & $\mathbf{1 4 4 5}$ & \multirow{2}{*}{ Jumlah Tuntas = } \\
\hline & Jumlah Rata-Rata & $\mathbf{8 1 0} \mathbf{x} \mathbf{1 0 0}=\mathbf{3 8 , 0 9 \%}$ \\
\hline & Presentasi Ketuntasan & &
\end{tabular}

Berdasarkan tabel di atas dapat dilihat bahwa hasil belajar yang dilakukan oleh siswa kelas VII sebelum menggunakan model pembelajaran langsung nilai terbesarnya adalah 85 dan nilai terkecil adalah 55 dengan jumlah 1445 dan nilai rata-rata 68,80 dengan nilai KKM 75 sehingga nilai presentasi ketuntasan yang diperoleh sebesar $38,09 \%$. berdasarkan nilai presentasi ketuntasan yang diperoleh siwa maka diperlukan sebuah metode pembelajaran yang dapat meningkatkan prestasi belajar siswa salah satunya dengan menggunakan model pembelajaran langsung. Dalam meningkatkan hasil belajar siswa di MTs Babussalam NW Pengadang Baru maka diciptakan kegiatan belajar mengajar yang menyenangkan, memotivasi peserta didik untuk berpartisipasi aktif, rapi dan tersusun yaitu diantaranya dengan menggunakan model pembelajaran langsung dengan metode demonstrasi dalam pelajaran fiqih.

Adapun untuk mengetahui sampai mana hasil belajar siswa atau tingkat prestasi siswa, maka guru mengadakan tes untuk para siswa. Untuk mengetahui sejauh mana tingkat kemampuan dan pemahaman siswa terhadap materi yang telah diajarkan, sorang 
guru perlu melakukan penilaian. Sedangkan untuk menentukan apakah pemahaman siswa meningkat atau tidak diperlukan adanya kriteria-kriteria. "penilaian sangat penting dalam sebuah pembelajaran, dengan adanya penilaian maka guru atau pendidik dapat mengetahui sejauh mana penguasaan materi yang telah dipelajari siswa. Dalam penilaian tentunya ada kriteria penilaian yang digunakan oleh guru. Adapun kriteria penilaian yang di gunakan sebagai berikut : nilai 8-9 = baik, 6-7 = cukup, dan 4-5 = kurang. Dengan KKM 75 yang telah di tetapkan di madrasah, jika sudah mencapai KKM maka siswa dapat dikatakan tuntas." (wawancara kepala sekolah: Siti Rauhun, S.Ag, kamis 24 september 2020 pukul 10: 56$)$.

Sesuai dengan hasil wawancara dengan guru fiqih bahwa: untuk dapat menentukan apakah setelah diadakan penelitian dengan menerapkan model pembelajaran langsung dalam kegiatan belajar mengajar di kelas, pemahaman siswa kelas VII MTs Babussalam NW Pengandang Baru tentang materi tata cara taharah meningkat atau tidak, maka cara yang dilakukan adalah mengklasifikasikan dan menentukan terlebih dahulu berapa banyak jumlah siswa yang memperoleh nilai baik, cukup, dan kurang. Peningkatan prestasi siswa dapat dilihat pada tabel di bawah ini:

Tabel 2

Nilai Siswa Setelah Menggunakan Model Pembelajaran Langsung

\begin{tabular}{|c|c|c|c|c|}
\hline No & Nama & KKM & NILAI & KETERANGAN \\
\hline 1 & Abdul Aziz Maqbul & 75 & 75 & Tuntas \\
\hline 2 & Ana Attopun Nisa & 75 & 80 & Tuntas \\
\hline 3 & Azizah & 75 & 85 & Tuntas \\
\hline 4 & Dani Isbullah & 75 & 70 & Tidak Tuntas \\
\hline 5 & Denil Arista Pratama & 75 & 80 & Tuntas \\
\hline 6 & Desi Lestari & 75 & 90 & Tuntas \\
\hline 7 & Desi Safitri & 75 & 80 & Tuntas \\
\hline 8 & Endri Setiawan & 75 & 85 & Tuntas \\
\hline 9 & Elsa Sulistia & 75 & 80 & Tuntas \\
\hline 10 & Eli Apriana & 75 & 75 & Tuntas \\
\hline 11 & Habib Burhanudin & 75 & 75 & Tuntas \\
\hline 12 & Jani Aprilia & 75 & 80 & Tuntas \\
\hline 13 & L Ahmad Aldinata & 75 & 65 & Tidak Tuntas \\
\hline 14 & M. Alparizi & 75 & 80 & Tuntas \\
\hline 15 & Moh. Kamaludin & 75 & 85 & Tuntas \\
\hline 16 & M. Kian & 75 & 80 & Tuntas \\
\hline 17 & Moh. Riski Pratama & 75 & 75 & Tuntas \\
\hline 18 & M. Yogi Akbar & 75 & 75 & Tuntas \\
\hline 19 & Raka Deny S & 75 & 70 & Tidak Tuntas \\
\hline 20 & Winda Rohana & 75 & 90 & Tuntas \\
\hline 21 & Serlina & 75 & 95 & Tuntas \\
\hline & $\begin{array}{l}\text { Jumlah } \\
\text { Jumlah Rata-Rata }\end{array}$ & & $\begin{array}{c}1670 \\
79,52 \\
\end{array}$ & Jumlah Tuntas = 18 \\
\hline & Presentasi ketuntasan & \multicolumn{3}{|c|}{$18: 21 \times 100=85,71 \%$} \\
\hline
\end{tabular}




\section{SIMPULAN}

Penerapan model pembelajaran langsung pada mata pelajaran fiqih dalam meningkatkan prestasi siswa di kelas VII MTs Babussalam NW Pengadang Baru tahun 2020/2021 dapat berjalan dengan lancar dengan langkah-langkahnya adalah melakukan tahap perencanaan: guru menyiapkan sumber belajar, lembar aktivitas siswa dan guru, lembar penilaian siswa, tahap pelaksanaan: guru menerapkan model pembelajaran langsung dengan menggunakan metode demonstrasi, dan tahap observasi: seorang guru mengamati setiap tingkah laku siswa dan kondisi kelas pada saat proses belajar mengajar berlangsung. Adapun kendala-kendala yang dihadapi guru dalam menerapkan model pembelajaran langsung pada mata pelajaran fiqih di kelas VII MTs Babussalam NW Pengadang Baru adalah kurang memadainya sumber belajar, kenakalan yang ada pada peserta didik, ketidakdisiplinaan peserta didik, alokasi waktu yang kurang dikarenakan pandemi Covid-19. Dengan diterapakannya model pembelajaran langsung pada mata pelajaran fiqih dalam meningkatkan prestasi siswa di MTs Babussalam NW Pengadang Baru dapat meningkatkan prestasi belajar siswa. Dengan meningkatnya prestasi belajar siswa maka penerapan model pembelajaran langsung untuk meningkatkan prestasi belajar siswa dikatakan berhasil. Hal ini dapat di lihat dari nilai yang diperoleh oleh siswa ketika guru mengevaluasi tingkat penguasaan pemahaman dan keterampilan siswa yaitu 18 dari 21 siswa yang mengikuti tes mengalami peningkatan atau tuntas.

\section{DAFTAR PUSTAKA}

Any. J. I. (2001). Pemanfaatan Sumber-Sumber Belajar dalam Proses Pembelajaran di SMPN 2 Lebaksiu Kabupaten Tegal. Doctoral dissertation. Universitas Negeri Semarang.

Arifin. Z., dan Aprianus. U. Z. (2020). Metodelogi Penelitian IImiah (Buku Panduan Mudah Memahami Metode IImiah dari Teori Hingga Aplikasi). Jogjakarta: Penerbit: KBM Indonesia.

Aunurrahman. (2016). Belajar dan Pembelajaran. Bandung: Alfabeta.

Djuwaini. D. (2015). Pengantar Fiqh Muamalah. Yogyakarta: Pustaka belajar.

Duren. S. N. K. (2014). "Pengaruh Penerapan Model Pembelajaran Kooperatif Tipe Stand Terhadap Peningkatan Prestasi Belajar Mata Pelajaran IPS Pada Siswa Kelas V."

Hawi. A. (2014. Kompetensi Guru Pendidikan Agama Islam. Jakarta: PT: RajaGrafindo Persada.

Mardani. (2013). Ushul Fiqh. Jakarta: PT. Raja Grafindo Persada.

Moleong. L. J. (2017). Metodelogi Penelitian Kualitatif. Bandung: PT: Remaja Rosdakarya.

Munif. E. B. (2019). Peningkatan Hasil Belajar Fiqih Materi Taharah (Najis dan Hadas) Dengan Metode Student Team Achievement Division (STAD) Pada Siswa Kelas VII A MTs. AL-MANAR Kecamatan Tengaran Kabupaten Semarang Tahun Pelajaran 2018/2019. Doctoral dissertation, IAIN SALATIGA.

Pritandhari. M. P. (2017). Implementasi Model Pebelajaran Direct Instruction Untuk Meningkatkan Kemampuan Berfikir Kreatif Mahasiswa. PROMOSI: Jurnal Program Studi Pendidikan Ekonomi.

Rasjid. S. (2011). Fiqih Islam. Bandung: Sinar Baru Algensindo.

Saebani. B. A. (2009). Ilmu Ushul Fiqh. Bandung: CV: Pustaka Setia.

Saebani. B. A., et all. (2015). Pengantar Ilmu Fiqh. Bandung: Pustaka Setia. 
Sugiyono. (2018). Metode Penelitian Pendidikan (Pendekatan Kuantitatif, Kualitataif, dan $R \& D)$. Bandung: Alfabeta.

Sumiati dan Asra. (2008). Metode pembelajaran. Bandung: CV Wacana Prima

Suprijono. A. (2015). Cooperative Learning Teori dan Aplikasi PAIKEM. Yogyakarta: Pustaka Pelajar.

Tirtarahardja. U. (2009). Pengantar Pendidikan. Jakarta: Rineka Cipta.

Wandasari. Y. (2017). "Implementasi Gerakan Literasi Sekolah (GLS) Sebagai Pebentuk Pendidikan Berkarakter". JMKSP (Jurnal Manajemen, Kepemimpinan, dan Supervisi Pendidikan).

Wiyani. N. A. (2016). Inovasi Kurikulum dan Pembelajaran PAI SMA Berbasis Pendidikan Karakter. Yogyakarta: AR-RUZZ MEDIA 